DOI: $10.4274 /$ tftr.56.111

\title{
Effect of Osteoporosis on Energy Expenditure of Resting and Daily Activities in Postmenopausal Women
}

\section{Osteoporozun Postmenopozal Kadınlarda Istirahat ve Günlük Aktiviteler SIrasındaki Enerji Tüketimine Etkisi}

\author{
Figen DAĞ, Uğur DAL, Özlem Bölgen ÇiMEN*, Resa ALTUN*, Hüseyin BEYDAĞl \\ Mersin Üniversitesi, Tıp Fakültesi, Fizyoloji Anabilim Dalı, Mersin, Türkiye \\ *Mersin Üniversitesi, Tıp Fakültesi, Fiziksel Tıp ve Rehabilitasyon Anabilim Dalı, Mersin, Türkiye
}

\begin{abstract}
Summary
Objective: The purpose of our study was to determine the effect of osteoporosis on energy expenditure and daily activities of postmenopausal women.

Materials and Methods: Eighteen recently diagnosed postmenopausal osteoporotic women without any fractures participated in this study. They were matched for age and body mass index with 19 postmenopausal nonosteoporotic women. Energy expenditure of postmenopausal women was measured using an indirect calorimetry during resting, sitting, standing and walking at speeds of $50 \mathrm{~m} / \mathrm{min}$ and $70 \mathrm{~m} / \mathrm{min}$. Quality of life of subjects was evaluated with the short form-36 (SF-36) questionnaire.

Results: There were no significant differences between groups for VO2 $(\mathrm{ml} / \mathrm{min})$ during resting, sitting, standing, and walking at speeds of 50 $\mathrm{m} / \mathrm{min}$ and $70 \mathrm{~m} / \mathrm{min}$. Bone mineral density (BMD) of the proximal femur was correlated with resting energy expenditure (REE) $(r=0.49, p=0.03)$ in postmenopausal osteoporotic women. The SF-36 bodily pain subscale score was significantly higher in postmenopausal osteoporotic women $(74.33 \pm 20.86)$ than in nonosteoporotic women $(58.10 \pm 17.09)$. The power of the study for detecting the differences was calculated as $71 \%$. Conclusion: The results seem to indicate that there is a relationship between BMD and REE in postmenopausal osteoporotic women. Although pain scores were higher in osteoporotic women, it was detected that they did not affect the energy expenditure of resting and at different physical activity levels. While determining the caloric intake of osteoporotic women and energy expenditure estimation in various daily physical activities, it can be taken into account that energy expenditure of osteoporotic women is similar to nonosteoporotic women. Turk J Phys Med Rehab 2010;56:111-5.

Key Words: Bone mineral density, DXA, energy expenditure, osteoporosis,
\end{abstract} quality of life, walking
Özet

Amaç: Çalışmamızın amacı osteoporozun postmenopozal kadınlarda enerji tüketimleri ve günlük aktiviteleri üzerine etkilerini araştırmaktır. Gereç ve Yöntem: Çalışmaya daha önce tanısı konmuş, kırığı olmayan 18 postmenopozal osteoporozlu kadın katıldı ve bunlar, yaş ve beden kitle indeksi bakımından 19 postmenopozal osteoporoz olmayan kadın ile eşleştirildi. İndirekt kalorimetri yöntemiyle postmenopozal kadınların; istirahat, oturma, ayakta durma ve $50 \mathrm{~m} / \mathrm{dk}, 70 \mathrm{~m} / \mathrm{dk}$ hızlarında yürüme sırasındaki enerji tüketimleri ölçüldü. Yaşam kaliteleri Short Form-36 (SF-36) anketiyle değerlendirildi.

Bulgular: Gruplar arasında, istirahat, oturma ve $50 \mathrm{~m} / \mathrm{dk}$ ve $70 \mathrm{~m} / \mathrm{dk}$ hızlarda yürüme esnasındaki VO2 ( $\mathrm{ml} / \mathrm{dk})$ parametreleri yönünden istatistiksel olarak anlamlı fark yoktu. Osteoporotik kadınlarda proksimal femur kemik mineral yoğunluğu ile istirahat enerji tüketimi arasında korelasyon gözlendi $(r=0,49, P=0,03)$. SF-36 anketinin "ağrı" alt grubu bakımından osteoporoz grubu puanları kontrollere göre anlamlı derecede yüksekti $(74,33 \pm 20,86$ ve $58,10 \pm 17,09)$. Çalışmanın farklılıkları tespit edebilme gücü $\% 71$ olarak hesaplanmıștır.

Sonuç: Sonuçlar, postmenopozal osteoporotik kadınlarda kemik mineral yoğunluğu ile istirahat enerji tüketimi arasında bir ilişki olduğunu göstermektedir. Osteoporozu olan kadınlarda, ağrı skorlarının yüksek olmasına rağmen istirahat ve farklı fiziksel aktivite düzeyindeki enerji tüketimini etkilemediği tespit edildi. Osteoporotik kadınların kalori alımlarında ve çeşitli günlük fiziksel aktivite düzeylerindeki enerji tüketimi hesaplanmalarında osteoporozu olan ve olmayan kadınların enerji tüketimlerinin benzer olduğu dikkate alınabilir. Türk Fiz Tıp Rehab Derg 2010;56:111-5.

Anahtar Kelimeler: Kemik mineral yoğunluğu, DXA, enerji tüketimi, osteoporoz, yaşam kalitesi, yürüme 


\section{Introduction}

Osteoporosis is a systemic skeletal disorder characterized by low bone mineral density (BMD) and structural deterioration of bone tissue with a consequent increase in bone fragility and susceptibility to fracture (1). It is a prevalent disorder that especially occurs in postmenopausal women (2). Estrogen deficiency is the most common reason for post-menopausal osteoporosis that causes a decrease in bone mass and provokes increment in bone fragility (3). Osteoporosis is defined clinically by the measurement of BMD, which is the most crucial indicator of bone strength and is an important marker used in determining fracture risk $(4,5)$. BMD is represented by the T-score which is the number of standard deviations (SD) above or below the mean reference value for a young healthy adult (4), and is assessed by dual-energy X-ray absorptiometry (DXA), that has become the gold standard for the diagnosis of osteoporosis $(5,6)$. Based on the 1994 WHO report, osteoporosis is defined as BMD value at least -2.5 SD below the mean value of young healthy populations, at the lumbar spine, hip, or total body (5).

Osteoporosis can also be identified as a social issue and has crucial clinical outcomes. Daily activities may be limited in women with osteoporosis, which may lead to altered emotional status and quality of life (7). The short form-36 (SF-36) questionnaire, comprising eight subscales, is a common tool used to evaluate the well-being. Patient with osteoporosis may experience some restrictions in daily physical activities because of pain (8). Hall et al. (9) suggested that women with osteoporosis with vertebral fractures had worse quality of life than women without osteoporosis. However, Lombardi et al. (10) reported similar SF-36 scores in the groups of osteoporotic women, osteoporotic women with fracture, and controls.

Resting, sitting, standing and walking are the regular activities of our daily life. Resting energy expenditure (REE) is the largest component of total energy expenditure. Choi et al. (11) showed that BMD correlates strongly with basal metabolic rate in postmenopausal women. Lombardi and his colleagues (10) reported that the energy expenditure during walking was not significantly different between patients with and without osteoporosis. Studies that investigated the energy expenditure at different physical activities and the relationship between BMD and REE in postmenopausal osteoporotic women are limited. The main purpose of the present study was to examine the differences between postmenopausal osteoporotic women and age-matched control group regarding energy expenditure during resting, sitting, standing and walking at 2 different speeds, and to evaluate quality of life in postmenopausal women with and without osteoporosis.

\section{Materials and Methods}

\section{Subjects}

Eighteen postmenopausal (whose last menstrual period was at least 1 year earlier) osteoporotic women (mean age: $56.06 \pm 5.64$ years) and 19 postmenopausal nonosteoporotic women (mean age: $54.37 \pm 5.61$ years), who applied to the Department of Physical Medicine and Rehabilitation, participated in our study. This study was approved by the local ethics committee, and informed consent was obtained from all subjects. Patients who met the diagnostic criteria of An update on the diagnosis and assessment of osteoporosis with densitometry were included in the study (5). The BMD of each subject was measured by DXA (Norland 45 XR, Norland Scientific Instruments, Fort Atkinson, WI, USA). Right hip and lumbar DXA measurements were performed in all patients by a licensed technician. According to DXA results, subjects with T-score below -2.5 constituted the osteoporotic group and those with T-score above -2.5 formed the nonosteoporotic group. None of the subjects had osteoporotic fractures and they were not exercising regularly. Patients with active infections, chronic systemic disase or metabolic disease (diabetes mellitus, hyperthyroidism, etc.) or patients using hormone replacement therapy were excluded. REE measurement was performed by one and the same investigator between 7:00-9:00 AM after a good night's sleep and an overnight fast (12 to 14 hours). Patients were instructed to refrain from exercise, smoking and alcohol on the day before the test.

\section{Anthropometry}

A general physical examination of each participant was conducted by an experienced physician. Weight and height were measured with subjects wearing light clothing and no shoes. Body mass index (BMI) was calculated as weight/height2 $\left(\mathrm{kg} / \mathrm{m}^{2}\right)$. Subcutaneous fat thickness was measured using a skinfold caliper (Holtain LTD., Crymych, UK) at three skin sites (triceps, suprailiac and thigh). Body density was estimated from the fat thickness by the Jackson and Pollock equations (12). The Siri's formula was used to convert the body density into body fat percentage (13).

\section{Metabolic Measurements}

Metabolic measurements were performed by an open-circuit indirect calorimetry (Vmax Spectra 29c; Sensormedics, Yorba Linda, CA, USA). Participants rested on supine position for 20 minutes prior to the REE measurement in a semi-darkened, quiet and empty room. Room temperature and humidity were maintained at $22-24^{\circ} \mathrm{C}$ and $50 \%$, respectively. The automated gas analyzer, calibrated before each test using $3 \mathrm{~L}$ syringe and standard gases of known concentration, was used to record respiratory parameters while subjects inspired room air through a free-breathing face mask. Expired and inspired gases were collected breath-by-breath for 30 minutes on supine positions. The first 10 minutes of $\mathrm{VO} 2$ and $\mathrm{CO} 2$ measurements were discarded and the last 20-min data were used for calculation of REE in steady-state period according to the abbreviated Weir equation (14). We instructed all subjects not to move and not to talk during REE measurement. Immediately after REE measurement, subjects sat on a comfortable chair for measurement of sitting energy expenditure, and then subjects stood up on the treadmill for 5 min for standing measurements, and walking energy expenditures at 2 different speeds $(50 \mathrm{~m} / \mathrm{min}$ and $70 \mathrm{~m} / \mathrm{min}$ ) were measured on the treadmill for 5 minutes for each phase. $\mathrm{O} 2$ consumption and $\mathrm{CO} 2$ production were measured using breath-by-breath indirect calorimetry. Firstly, the progressive walking test was started with warm-up period at low speed on treadmill (Viasys Health Care, LE 200 CE, OH, USA). Then, speed was increased to $50 \mathrm{~m} / \mathrm{min}$ and, the last stage was maintained at $70 \mathrm{~m} / \mathrm{min}$. Oxygen data of the last 2 minutes of recordings were accepted as the steady-state period and averaged at 10-s intervals for analyzing each phase $(15,16)$. 


\section{Short Form-36}

Each subject was asked to fill out the SF-36 quality of life questionnaire, which was self-administered in the standardized manner, with no interpretation of the questions by the interviewer. The SF-36 consists of 36 items that are employed to calculate scores on eight dimensions: physical function, role limitation due to physical health problems, bodily pain, general health, vitality, social function, role limitation due to emotional health problems, and mental health (17). Each SF-36 domain is scored on a scale with a range from 0 to $100(17,18)$.

\section{Statistical Analyses}

The statistical results of parameters were presented as means and SDs in descriptive statistics tables. Distribution of demographic data and metabolic measurements was controlled with Shapiro-Wilk normality test. Mean values of demographic and metabolic variables of osteoporotic and nonosteoporotic groups were compared with Student-t test and Mann-Whitney $U$ test according to their distributions. To assess the linear relationship between BMD and REE, Pearson correlation coefficient was used. SPSS 11.5.1 for Windows (SPSS Inc, 233 S Wacker Dr, 11th Fl, Chicago, IL 60606) was used for statistical analysis. The level of significance was set at $p<0.05$ in all analysis.

\section{Results}

Means and SDs of demographic, anthropometric, and densitometric data of women according to groups are summarized in Table 1. There were no significant differences between postmenopausal osteoporotic group and nonosteoporotic group in age, height, weight and BMI, a fact, demonstrating their homogeneity. However, total body fat percentage in osteoporotic women was significantly lower than in nonosteoporotic women $(36.73 \pm 5.23$ and $40.23 \pm 3.42$, respectively; p<0.05).

The SF-36 bodily pain subscale score was significantly higher in postmenopausal osteoporotic women than in nonosteoporotics $(74.33 \pm 20.86$ and $58.10 \pm 17.09$, respectively; $p<0,05$ The other subscales showed no significant differences between both groups (Figure 1).

There were no significant differences between two groups in oxygen consumption during resting, sitting, standing, and walking

Table 1. Demographic, anthropometric, and densitometric data of women according to groups.

\begin{tabular}{|c|c|c|}
\hline Variables & $\begin{array}{c}\text { Nonosteoporotic } \\
\text { group }(n=19)\end{array}$ & $\begin{array}{l}\text { Osteoporotic } \\
\text { group }(n=18)\end{array}$ \\
\hline Age (year) & $54.37 \pm 5.61$ & $56.06 \pm 5.64$ \\
\hline Height (m) & $1.56 \pm 0.06$ & $1.54 \pm 0.05$ \\
\hline Weight (kg) & $70.13 \pm 10.46$ & $67.33 \pm 10.66$ \\
\hline BMI $\left(\mathrm{kg} / \mathrm{m}^{2}\right)$ & $28.84 \pm 4.72$ & $28.09 \pm 4.42$ \\
\hline Total body fat percentage (\%) & $40.23 \pm 3.42$ & $36.73 \pm 5.23 *$ \\
\hline Duration of menopause (year) & $5.76 \pm 6.05$ & $10.13 \pm 7.71^{*}$ \\
\hline BMD lumbal $\left(\mathrm{g} / \mathrm{cm}^{2}\right)$ & $0.90 \pm 0.14$ & $0.55 \pm 0.10 *$ \\
\hline BMD femur $\left(\mathrm{g} / \mathrm{cm}^{2}\right)$ & $0.85 \pm 0.09$ & $0.77 \pm 0.13 *$ \\
\hline
\end{tabular}

at 2 different speeds. Energy expenditures of both groups were tested with Student-t test and Mann-Whitney $U$ test according to their distributions. REE was $1137.51 \pm 208.33 \mathrm{kcal} /$ day in postmenopausal osteoporotic women and $1179.83 \pm 134.03$ $\mathrm{kcal} /$ day in nonosteoporotic group, which was not significantly different. Pearson's correlation coefficient was calculated to determine the linear relationship between BMD and REE. In osteoporotic women, proximal femur BMD was correlated with REE $(r=0.49, p=0.03)$. Neither sitting nor standing energy expenditure was statistically different between postmenopausal osteoporotic women $(1312.83 \pm 270.66 \mathrm{kcal} / \mathrm{day}$ and $1359.04 \pm 193.60 \mathrm{kcal} / \mathrm{day}$, respectively) and nonosteoporotic women $(1360.43 \pm 263.83$ $\mathrm{kcal} /$ day and $1453.32 \pm 196.42 \mathrm{kcal} /$ day, respectively).

During walking at the speed of $50 \mathrm{~m} / \mathrm{min}$ oxygen consumption was $11.05 \pm 1.83 \mathrm{ml} / \mathrm{kg} / \mathrm{min}$ in postmenopausal osteoporotic women and $11.13 \pm 1.62 \mathrm{ml} / \mathrm{kg} / \mathrm{min}$ in postmenopausal nonosteoporotic group. At the speed of $70 \mathrm{~m} / \mathrm{min}$ it was $13.67 \pm 1.89 \mathrm{ml} / \mathrm{kg} / \mathrm{min}$ in postmenopausal osteoporotic women and $14.15 \pm 3.23 \mathrm{ml} / \mathrm{kg} / \mathrm{min}$ in postmenopausal nonosteoporotic group.

\section{Discussion}

In the present study, we observed no significant differences between postmenopausal osteoporotic and nonosteoporotic women in metabolic parameters during resting and at different physical activity levels.

Total body weight, percentage of body fat, and BMI are important factors that may affect the bone mineral density in postmenopausal osteoporosis (19). Several studies have suggested that fat mass has a protective impact against loss of bone mass (20-23). The mechanism by which fat mass is protective is not known clearly, but may involve the peripheral synthesis of estrogen by adipose tissue, the effect of weight on mechanical loading on the skeleton and the relationship of fat mass with secretion of bone-active hormones from the pancreas $(24,25)$. This information supports the findings that total body fat percentage in osteoporotic women was significantly lower than in nonosteoporotic women in our study. Furthermore, Reid et al. (22) and Compston et al. (23) also suggested that total body fat was the most important predictor of bone mass in postmenopausal women.

$\mathrm{REE}$, the largest component of daily energy expenditure, tends to decrease as age increases in women. A greater reduction in REE may occur with the onset of menopause $(26,27)$.

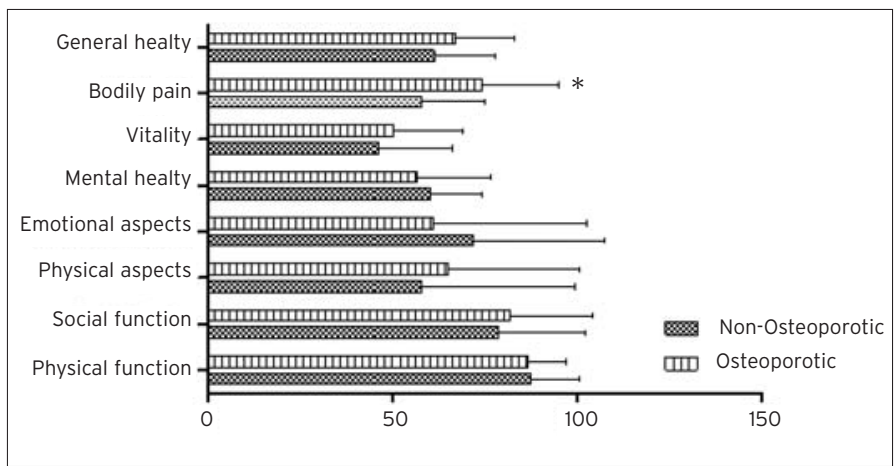

Figure 1. The short form-36 quality of life questionnaire for each of the 8 domains for postmenopausal osteoporotic women and nonosteoporotic group. *Statistically significant $(\mathrm{P}<0.05)$. 
The duration of menopause was significantly lower in the nonosteoporotic group in our study. This may result in decreased estrogen level, because if the duration of menopause increases, the decrement in estrogen level will be higher (28). Thus, it was expected that there would be a difference between the two groups in REE and in the other energy expenditure measurements. However, nonosteoporotic women had higher total body fat percentage in the present study, which may cause a decrease in REE. This may be the explanation why energy expenditure in both nonosteoporotic and osteoporotic groups is not significantly different. There was a positive correlation between REE and proximal femur BMD in the osteoporotic group, but not in the nonosteoporotics in our study. However, there was no correlation between REE and lumbar spine BMD in both groups. Since the effect of weight-bearing and biomechanical force on BMD of lumbar spine and proximal femur can be different, it could be assumed that the appearance of osteoporosis may differ depending on measurement areas (11). Haffner et al. (29) reported that as age increased, decrement in lumbar BMD values was slower than decrement in femur BMD values. Afghani et al. $(30,31)$ demonstrated that BMD of proximal femur and lumbar spine correlated positively with REE. Likewise, Choi et al. (11) showed that BMD associated strongly with basal metabolic rate in postmenopausal women.

Walking is a common type of exercise for all people at every physical activity level (32). According to Pollock et al. (33), 20 to 60 minutes of continuous activity at moderate intensity needs to be performed to maintain cardio-respiratory fitness and body composition. In the review of Bonaiuti et al. (34), it was reported that different types of exercise, such as aerobics, weight bearing and resistance, had strong effect on the BMD of the spine in postmenopausal women. It was concluded that the abovementioned exercise types might lead to an increase in the BMD of the spine in postmenopausal women. Therefore, one of the purposes of our study was to determine energy expenditure in various physical activities such as sitting, standing and walking. These findings can be used as a guide to create a physical rehabilitation program for postmenopausal osteoporotic women. However, we did not find any significant differences between postmenopausal osteoporotic and nonosteoporotic groups in energy expenditure and oxygen consumption during sitting, standing, and walking at speeds of $50 \mathrm{~m} / \mathrm{min}$ and $70 \mathrm{~m} / \mathrm{min}$ in our study. Lombardi et al. (10) demonstrated that energy expenditure during standing on the treadmill was significantly higher in osteoporotic women with vertebral fracture than in osteoporotic women without fracture. However, three study groups (osteoporotic women with vertebral fracture, osteoporotic women without fracture, and control group) did not differ significantly from each other in energy expenditure during walking at $3 \mathrm{~km} / \mathrm{h}$ and $4 \mathrm{~km} / \mathrm{h}$. These results support our findings that there were no significant differences between the osteoporotic and control groups in energy expenditure during walking at speeds of $50 \mathrm{~m} / \mathrm{min}(3 \mathrm{~km} / \mathrm{h})$ and $70 \mathrm{~m} / \mathrm{min}(4.2 \mathrm{~km} / \mathrm{h})$. These results of our study may have clinical implications for therapies targeting to improve gait economy in postmenopausal osteoporotic women without fractures.

In osteoporotic patients, besides physical symptoms, the quality of life becomes deteriorated because of limitations in their daily and social activities. For this purpose, SF-36 is used to evaluate patient's quality of life (17). Several studies primarily focused on osteoporotic women with fracture and only evaluated the effect of fracture on quality of life in this specific population (9,35-37). Hall et al. (9) observed a statistically significant difference between osteoporotic women with vertebral fractures and women without osteoporosis in all SF-36 domains. In our study, only "bodily pain" score, a subscale of the SF-36, was significantly higher in postmenopausal osteoporotic women than in the nonosteoporotic group, but it did not affect the energy expenditure values of resting and at different physical activity levels. The reason for this could be that vertebral fractures were present in none of the women in our study, while the women in the study of Hall et al. had 2.9 vertebral fractures on average. Ferreira et al. (38) observed significant differences in all domains of SF-36 between osteoporotic and nonosteoporotic women. Women with osteoporosis had lower SF-36 scores. Also, Lombardi et al. (10) showed that there were no significant differences among the osteoporotic group with vertebral fractures, osteoporotic group without fractures, and the control group in the subgroups of SF-36 questionnaire.

The first limitation of our study is that the nonosteoporotic group consisted of osteopenia patients (Osteopenia is defined by a T score between -1 and -2.5 ) and controls (T score $>-1$ ); it is difficult to find postmenopausal women who do not have osteopenia at these ages. The second limitation is that estrogen levels of women were not measured because of inadequate financial sources of this study. We are planning new studies on the energy expenditure during resting and at different physical activity levels and in women with osteopenia and osteoporosis in different age groups that might lead to a better understanding of the relationship between energy expenditure and osteoporosis.

\section{Conclusion}

The energy expenditure during resting and at different physical activity levels in postmenopausal osteoporotic women without fractures was in the same level as in postmenopausal nonosteoporotic women. Our results emphasize that REE correlated strongly with BMD in postmenopausal osteoporotic women that may have implications for determining the impairment of BMD in postmenopausal women.

\section{References}

1. Consensus Development Conference. Prophylaxis and treatment of osteoporosis. Osteoporos Int 1991;1:114-7. [Full Text] / [PDF]

2. Parvez T. Postmenopausal Osteoporosis. JK Pract 2004;11:281-3.

3. Wellington K, Plosker GL. Management of postmenopausal osteoporosis: Defining the role of raloxifene. Dis Manage Health Outcomes 2003;11:673-92. [Abstract]

4. Turner $\mathrm{CH}$, Burr DB. Basic biomechanical measurements of bone: a tutorial. Bone 1993;14:595-608. [Abstract]

5. Kanis JA, Gluer CC. An update on the diagnosis and assessment of osteoporosis with densitometry. Committee of Scientific Advisors, International Osteoporosis Foundation. Osteoporos Int 2000;11:192-202. [Abstract]

6. Lewiecki EM. Clinical applications of bone density testing for osteoporosis. Minerva Med 2005:96:317-30. [Abstract]

7. Aranha LLM, Mirón Canelo JA, Alonso Sardón M, Del Pino Montes J, Sáenz González MC. Health-related quality of life in Spanish women with osteoporosis. Rev Saude Publica 2006;40:298-303. [Abstract] / [Full Text] / [PDF] 
8. Cook DJ, Guyatt GH, Adachi JD, Epstein RS, Juniper EF, Austin PA, et al. Development and validation of the mini-osteoporosis quality of life questionnaire (OQLQ) in osteoporosis women with back pain due to vertebral fractures. Osteoporos Int 1999;10:207-13. [Abstract]

9. Hall SE, Criddle RA, Comito TL, Prince RL. A case-control study of quality of life and functional impairment in women with long-standing vertebral osteoporotic fracture. Osteoporos Int 1999;9:508-15. [Abstract]

10. Lombardi I Jr, Oliveira LM, Monteiro CR, Confessor $Y Q$, Barros TL, Natour J. Evaluation of physical capacity and quality of life in osteoporotic women. Osteoporos Int 2004;15:80-5. [Abstract] / [PDF]

11. Choi JW, Pai SH. Bone mineral density correlates strongly with basal metabolic rate in postmenopausal women. Clin Chim Acta 2003;333:79-84. [Abstract] / [Full Text] / [PDF]

12. Jackson AS, Pollock ML,Ward A. Generalized equations for predicting body density of women. Med Sci Sports Exerc 1980;12:175-82. [Abstract]

13. Siri WE. The gross composition of the body. Adv Biol Med Phys 1956:4:239-80. [Abstract]

14. Matarese LE. Indirect calorimetry: technical aspects. J Am Diet Assoc 1997:97:154-60. [Abstract]

15. Ozyener F, Rossiter HB, Ward SA, Whipp B J. Influence of exercise intensity on the on- and off-transient kinetics of pulmonary oxygen uptake in humans. J Physiol 2001;533;891-902. [Abstract] / [Full Text] / [PDF]

16. Traballesi M, Porcacchia P, Averna T, Brunelli S. Energy cost of walking measurements in subjects with lower limb amputations: A comparison study between floor and treadmill test. Gait Posture 2008;27:70-5. [Abstract] / [Full Text] / [PDF]

17. Ware JE Jr. SF-36 health survey update. Spine 2000;25:3130-9. [Abstract]

18. Brazier JE, Harper R, Jones NM, O'Cathain A, Thomas KJ, Usherwood T, et al. Validating the SF-36 health survey questionnaire: new outcome measures for primary care. BMJ 1992;305:160-4. [Abstract] / [PDF]

19. Ravn P, Cizza G, Bjarnason NH, Thompson D, Daley M, Wasnich RD, et al. Low body mass index is an important risk factor for low bone mass and increased bone loss in early postmenopausal women. Early Postmenopausal Intervention Cohort (EPIC) study group. J Bone Miner Res 1999;14:1622-7. [Abstract] / [PDF]

20. Zhao LJ, Jiang H, Papasian CJ, Maulik D, Drees B, Hamilton J, et al. Correlation of obesity and osteoporosis: effect of fat mass on the determination of osteoporosis. J Bone Miner Res 2008;23:17-29. [Abstract] / [PDF]

21. Rosen CJ, Bouxsein ML. Mechanisms of disease: is osteoporosis the obesity of bone? Nat Clin Pract Rheumatol 2006;2:35-43. [Full Text] / [PDF]

22. Reid IR, Ames R, Evans MC, Sharpe $S$, Gamble G, France JT, et al. Determinants of total body and regional bone mineral density in normal postmenopausal women-a key role for fat mass. J Clin Endocrinol Metab 1992:75:45-51. [Abstract] / [PDF]

23. Compston JE, Bhambhani M, Laskey MA, Murphy S, Khaw KT. Body composition and bone mass in post-menopausal women. Clin Endocrinol 1992;37:426-31. [Abstract]
24. Öner C, Avcı GK, Tosunoğlu F. Postmenopozal Kadınlarda Obesite, İnsülin Düzeyi Ve Kemik Mineral Yoğunluğu Arasındaki İlișkiler. Türk Fiz Tip Rehab Derg 2001;47:24-7 [Abstract] / [Full Text]

25. Reid IR. Relationships among body mass, its components, and bone. Bone 2002;31:547-55. [Abstract] / [Full Text] / [PDF]

26. Poehlman ET, Toth MJ, Gardner AW. Changes in energy balance and body composition at menopause: a controlled longitudinal study. Ann Intern Med 1995;123:673-5. [Abstract] / [Full Text] / [PDF]

27. Poehlman ET. Menopause, energy expenditure, and body composition. Acta Obstet Gynecol Scand 2002;81:603-11. [Abstract] / [PDF]

28. Klaiber EL, Broverman DM, Vogel W, Peterson LG, Snyder MB. Relationships of serum estradiol levels, menopausal duration, and mood during hormonal replacement therapy. Psychoneuroendocrinology 1997:22:549-58. [Abstract] / [PDF]

29. Haffner SM, Bauer LR. The association of obesity and glucose and insülin concentrations with bone density in premenopausal and postmenopausal women. Metabolism 1993;42:735-8. [Abstract]

30. Afghani A, Barrett-Connor E, Wooten WJ. Resting energy expenditure: a better marker than BMI for BMD in African-American women. Med Sci Sports Exerc 2005;37:1203-10. [Abstract]

31. Afghani A, Barrett-Connor E. Resting energy expenditure: a stronger marker than body weight for bone mineral density in white women but not men? The Rancho Bernardo study. Clin J Sport Med 2009:19:39-45. [Abstract]

32. Anjos LA, Wahrlich V, Bossan FM, Salies MN, Silva PB. Energy expenditure of walking at different intensities in Brazilian college women. Clin Nutr 2008;27:121-5. [Abstract] / [Full Text] / [PDF]

33. Pollock ML, Gaesser GA, Butcher JD, Després J-P, Dishman RK, Franklin BA, Janus D, Barry A, Garber, Carol E.American College of Sports Medicine Position Stand on the recommended quantity and quality of exercise for developing and maintaining cardiorespiratory and muscular fitness, and flexibility in healthy adults. Med Sci Sports Exerc 1998;30:975-91. [Abstract] / [Full Text]

34. Bonaiuti D, Shea B, Lovine R, Negrini S, Welch V, Kemper HHCG, WIIs GA. Exercise for preventing and treating osteoporosis in postmenopausal women. Cochrane Database Syst Rev 2002;3:CD000333. [Abstract] / [Full Text]

35. Lips P, Cooper C, Agnusdei D, Caulin F, Egger P, Johnell O, et al. Quality of life in patients with vertebral fractures: validation of the quality of life questionnaire of the European foundation for osteoporosis (QUALEFFO). Osteoporos Int 1999:10:150-60. [Abstract]

36. Fechtenbaum J, Cropet C, Kolta S, Horlait S, Orcel P, Roux C. The severity of vertebral fractures and health-related quality of life in osteoporotic postmenopausal women. Osteoporos Int 2005;16:2175-9. [Abstract] / [PDF]

37. Cockerill W, Lunt M, Silman AJ, Cooper C, Lips P, Bhalla AK, et al. Health-related quality of life and radiographic vertebral fracture. Osteoporos Int 2004;15:113-9. [Abstract] / [PDF]

38. de Oliveira Ferreira $N$, Arthuso $M$, da Silva $R$, Pedro AO, Neto AM, Costa-Paiva L. Quality of life in women with postmenopausal osteoporosis: Correlation between QUALEFFO 41 and SF-36. Maturitas 2009;62:85-90. [Abstract] 